\title{
Q.
QNEEN'S
UNIVERSITY
BELFAST
}

\section{Climate and Civilization}

Livingstone, D. (2020). Climate and Civilization. In Climate in American Literature and Culture (pp. 58-74). Cambridge University Press. https://doi.org/10.1017/9781108505321

\section{Published in:}

Climate in American Literature and Culture

\section{Document Version:}

Peer reviewed version

\section{Queen's University Belfast - Research Portal:}

Link to publication record in Queen's University Belfast Research Portal

\section{Publisher rights}

Copyright 2020 Cambridge University Press. This work is made available online in accordance with the publisher's policies. Please refer to any applicable terms of use of the publisher.

\section{General rights}

Copyright for the publications made accessible via the Queen's University Belfast Research Portal is retained by the author(s) and / or other copyright owners and it is a condition of accessing these publications that users recognise and abide by the legal requirements associated with these rights.

\section{Take down policy}

The Research Portal is Queen's institutional repository that provides access to Queen's research output. Every effort has been made to ensure that content in the Research Portal does not infringe any person's rights, or applicable UK laws. If you discover content in the Research Portal that you believe breaches copyright or violates any law, please contact openaccess@qub.ac.uk. 


\section{Climate and Civilization}

David N. Livingstone

Chapter for

Michael Boyden (ed), Climate in American Literature and Culture

\section{Prophecy by Degree}

On 9 August, 2008, National Geographic Channel premiered its television show "Six Degrees Could Change the World." The broadcast was accompanied by an ongoing, fully interactive website inviting visitors to explore the world's future at different degrees of global warming. ${ }^{1}$ Enter the site and a map of the world with what could be called a "disaster dial" appeared on the screen. In line with the television program, viewers were confronted with dire warnings. A prophetic history of the future unfolded literally by degree. Click the dial for two degrees Celsius warmer and urban Bolivians move into rural areas in search of water; point five on the dial brings worldwide political upheaval, economic disaster and armed conflict; at six degrees cities are unsustainable, communication systems break down as infrastructure crumbles, and emergency alert systems disintegrate. Civilization has collapsed.

Voices prophesying humanity's climatic destiny are common as a mere smattering of "degree diagnostics" will surely illustrate. The United States National Bureau of Economic Research, for instance, using temperature change as a kind of economic thermometer, reports that one degree Celsius increase in temperature in poorer countries "predicts a fall in per capita income by ... about 8 per cent." ${ }^{2}$ The Age of Consequences, a Pentagonorientated report prepared for the Centre for a New American Security, informs readers than a 2.6 degrees Celsius rise in temperature will bring "massive social upheaval ... accompanied by intense religious and ideological turmoil". At a further three degrees increase multiple calamities converge "in one conflagration: rage at government's inability to deal with the abrupt and unpredictable crises; religious fervour, perhaps even a dramatic rise in millennial end-of-days cults; ... and intra- and interstate conflict over resources." ${ }^{3}$

\section{A Deeper History}

In many ways these eschatological prognostications continue a long tradition of finding the fate of civilizations in the state of the atmosphere. Frequently the term 'climatic determinism' has been used to characterise those espousing this way of thinking. More recently, in the wake of developments in climate modelling, the label 'climatic reductionism' has come to the fore. In Mike Hulme's telling the latter designation is intended to capture a suite of new methodological practices that deliver what he refers to as "neoenvironmental

\footnotetext{
1 "Six Degrees Could Change the World", National Geographic Channel. http://channel.nationalgeographic.com/channel/sixdegrees/

${ }^{2}$ Melissa Dell, Benjamin F. Jones and Benjamin A. Olken, Climate Change and Economic Growth: Evidence from the Last Half Century (Cambridge, Mass: National Bureau of Economic Research, 2008, Working Paper No. 14132)

${ }^{3}$ Kurt M. Campbell, et al., The Age of Consequences: The Foreign Policy and National Security Implications of Global Climate Change (Washington, D.C.: Centre for Strategic and International Studies, and Centre for a New America Security, 2007), pp. 77, 85
} 
determinism." ${ }^{4}$ As Hulme himself puts it, while "climate determinism is easy to caricature and easy to dismiss as hopelessly naïve, there are more sophisticated variants circulating today which ... I have referred to as 'climate reductionism' ${ }^{\prime \prime}{ }^{5}$ Whatever the differences between 'climatic determinism' and 'climatic reductionism' the impulse remains the same; both identify climate as a, if not the, primary explanans of human life and culture. That proclivity is my quarry in this chapter, bearing in mind that determinisms come in a range of different styles, some more exclusivist and extreme than others.

The roots of this inclination can be traced back to the ancient world. The later sections of the Hippocratic Airs, Waters and Places, for example, a treatise written to assist travelling medical practitioners, called attention to the power of climate to mould human character and constitution. ${ }^{6}$ Thus the Hippocratics attributed fundamental differences between the European and Asiatic psyche to the sovereignty of climate. Typifying the Asiatic as displaying "pusillanimity and cowardice," they insisted that "the principal reason the Asiatics are more unwarlike and of gentler disposition than the Europeans is the nature of the seasons, which do not undergo any great changes either to heat or cold." In Europe, cowardice gave way to courage, timidity to pugnacity. Why? Because European climates were variable with hot summers, cold winters, frequent rains and droughts. As Airs, Waters and Places explained, "a climate which is always the same induces indolence, but a changeable climate, laborious exertions both of body and mind; and from rest and indolence cowardice is engendered, and from laborious exertions and pains, courage." 7

The penchant for finding in climate the foundations of the social order conspicuously manifested itself in the writings of the fourteenth century Islamic student of civilization, Ibn Khaldūn (1332-1406). ${ }^{8}$ His reputation as a founder of the climate and civilization school of global history largely rests on his historiographical reflections in his celebrated introduction to history, Al Muqadimmah, which he completed in 1377. Here, following Ptolemy and AlIdrisi in dividing the ecumene into seven latitudinal zones, he pondered why "[c]ivilization has its seat between the third and the sixth zones" while the "south is all emptiness." The reason lay in "the excessive heat and slightness of the sun's deviation from the zenith in the south." This meant that there was "little civilization in the first and second zones", "a medium degree of civilization in the third, fourth, and fifth zones, because the heat there is temperate owing to the decreased amount of light" and "a great deal of civilization in the sixth and seventh zones because of the decreased amount of heat there." ${ }^{9}$ In Ibn Khaldūn's

\footnotetext{
${ }^{4}$ Mike Hulme, "Reducing the Future to Climate: A Story of Climate Determinism and Reductionism", Osiris 26, No. 1, Klima (2011): pp. 245-266, on p. 249.

${ }^{5}$ Mike Hulme, Weathered: Cultures of Climate (Los Angeles: Sage, 2017), p. 69.

${ }^{6}$ There are numerous surveys of Hippocratic environmentalism. See, for example, Caroline Hannaway, "Environment and Miasmata," in W.F. Bynum and Roy Porter (eds), Companion Encyclopedia of the History of Medicine (Abingdon: Routledge, 1993), pp. 292-308; Roy Porter, The Greatest Benefit to Mankind: A Medical History of Humanity from Antiquity to the Present (London: HarperCollins, 1997), pp. 55-62; Clarence J. Glacken, Traces on the Rhodian Shore: Nature and Culture in Western Thought from Ancient Times to the End of the Eighteenth Century (Berkeley: University of California Press, 1967)

${ }^{7}$ Hippocrates, On Airs, Waters and Places, translated by Francis Adams, parts 16, 23. Available at: http://classics.mit.edu/Hippocrates/airwatpl.1.1.html

${ }^{8}$ See, from different perspectives, Nathaniel Schmidt, Ibn Khaldûn, Historian, Sociologist and Philosopher (New York: Columbia Press, 1930); Allen James Fromherz, Ibn Khaldun, Life and Times (Edinburgh: Edinburgh University Press 2010); Robert Irwin, Ibn Khaldun: An Intellectual Biography (Princeton: Princeton University Press, 2018)

${ }^{9}$ Ibn Khaldūn, The Muqaddimah: An Introduction to History, translated by Franz Rosenthal, 3 vols (Princeton, N.J.: Princeton University Press, 1967), vol. 1, pp. 93, 95
} 
cosmos, as Fromherz observes, "[t]he clockwork of the body and the clockwork of nature were the clockwork of society." 10 And so he elaborated a global geography of civilization. Because the "inhabitants of the middle zones are temperate in their physique and character and in their ways of life," he remarked, they had "all the natural conditions necessary for a civilized life, such as ways of making a living, dwellings, crafts, sciences, political leadership, and royal authority."11

Perhaps the most celebrated reworking of climatic Hippocratism crystallized in the writings of Montesquieu (1689-1755). In The Spirit of the Laws (1748), he began his reflections "On the Laws in their Relation to the Nature of the Climate" with the assertion that "[i]f it is true that the character of the spirit and the passions of the heart are extremely different in the various climates, laws should be relative to the differences in these passions and to the differences in these characters." The ultimate reason for this global geography of differentiated legislation lay in how Montesquieu conceived the operations of the cardiovascular system. "Cold air contracts the extremities of the body's surface fibres," he explained; and "this increases their spring, and favors the return of blood from the extremities of the heart. It shortens these same fibres; therefore, it increases their strength in this way too. Hot air, by contrast, relaxes these extremities of the fibres and lengthens them; therefore, it decreases their strength and their spring." Cultural and moral consequences ensued. "You will find in the northern climates peoples who have few vices, enough virtues, and much sincerity and frankness," he announced. "As you move toward the countries of the south, you will believe you have moved away from morality itself: the liveliest passions will increase crime; each will seek to take from others all the advantages that can favour these same passions." 12

The naturalization of social life found later expression in the writings of the English historian, Henry Thomas Buckle (1821-1862), most notably in his History of Civilization in England. In seeking an appropriate historical methodology, Buckle posed the question: "Are the actions of men, and therefore of societies, governed by fixed laws, or are they the result either of chance or of supernatural interference?" His answer was clear. Human behaviour was regulated by natural law and thus "the possibility of a science of history" was entirely achievable. The statistical wizardry of Adolphe Quetelet, who applied numerical techniques to elucidating the relationship between crime and age, climate, poverty and the like, was ample proof that there was "an intimate connexion between human actions and physical laws." In prosecuting this vision, Buckle turned to climate, food and soil as the "physical agents" that had not only "originated the most important consequences in regard to the general organization of society" but also determined "many of those large and conspicuous differences between nations." In Buckle's telling, provender, pedology, and politics were intimately intertwined through their links with climate. As he summarized his food philosophy: "the laws of climate are, through the medium of food, connected with the laws of population, and therefore with the laws of the distribution of wealth." This was simply because of "all the results which are produced among a people by their climate, food, and

\footnotetext{
${ }^{10}$ Fromherz, Ibn Khaldun, Life and Times, p. 138

${ }^{11}$ Ibn Khaldūn, The Muqaddimah, vol. 1, p. 172

12 Baron de Montesquieu, The Spirit of the Laws, Cambridge Texts in the History of Political Thought, translated and edited by Anne M. Cohler, Basia Carolyn Miller and Harold Samuel Stone (Cambridge: Cambridge University Press, 1989), Book XIV, §1, §2
} 
soil, the accumulation of wealth is the earliest, and in many respects the most important."13 To be sure, Buckle's was not an irresistibly crude reductionism. But he certainly did foreground climate as a major driver of history and thereby gave inspiration to later likeminded students of civilization.

\section{An American Coalition}

In his History of the Intellectual Development of Europe as well as his History of the American Civil War, John William Draper (1811-1882), President of New York University, chemist, and architect of the "conflict model" of science and religion, likewise aspired to scientific history, and "undoubtedly profited from the vogue" that Buckle's writings stimulated. ${ }^{14}$ Climate figured prominently in his account of Europe's intellectual evolution. Harking back to Jean Bodin, the sixteenth-century political philosopher and theorist of sovereignty, he announced that "the laws of Nature cannot be subordinated to the will of Man, and that government must be adapted to climate." Accordingly, he was sure that with "difference of climate there must be differences of manners and customs, that is, differences in the modes of civilization." To Draper, variety of climate was the spice of civilized life: "Where there are many climates there will be many forms of men. Herein ... lies the explanation of the energy of European life, and the development of its civilization." 15

In the History of the American Civil War, Draper announced "the great truth that societies advance in a preordained and inevitable course" on account of "uncontrollable causes," chief among which was climate. ${ }^{16}$ In consequence the first volume of his narrative contained chapters devoted to the general effects of climate, its particular influence on the human race, and to the "Identification of National Character by Climatic Zones." More specifically, Draper was convinced that the "differentiation" of the American nation "into two sections, conveniently known as the North and the South, or the free and the slave powers" had been effected "chiefly through the agency of climate." This climate-driven disjunction had produced a geopolitical bi-polarity ripe for internecine hostility. "A selfconscious democracy, animated by ideas of individualism, was the climate issue in the North," he declared; "an aristocracy, produced by sentiments of personal independence and based upon human slavery, was the climate issue in the South - an aristocracy sub-tropical in its attributes, ... imperious to its friends, ferocious to its enemies, and rapidly losing the capacity of vividly comprehending European political ideas." Climate's orchestrating of the temperamental disjunction and economic disparity between North and South inevitably fostered different labour systems. "The climate of the South," he insisted, "through the agricultural products it permitted, favored plantation life and the institution of slavery, and hence it promoted a sentiment of independence in the person and of state-rights in the community; that of the North intensified in the person a disposition to individualism, and in

\footnotetext{
${ }^{13}$ Henry Thomas Buckle, History of Civilization in England new edition (London: Longmans, Green, and Co., 1873), 3 vols, Vol 1, pp. 8, 33, 18, 39, 57, 41. See also Bernard Semmel, "H.T. Buckle: The Liberal Faith and the Science of History," British Journal of Sociology 27 (1976): 371-386

${ }^{14}$ Donald Fleming, "Draper, John William," Complete Dictionary of Scientific Biography, available online at: https://www.encyclopedia.com/people/science-and-technology/chemistry-biographies/john-william-draper ${ }^{15}$ John William Draper, History of the Intellectual Development of Europe, 2 vols (London: Bell and Daldy, 1864), pp. 6, 11, 27

${ }^{16}$ John William Draper, History of the American Civil War, 3 vols (New York: Harper, 1867), Vol. 1, p. iii. Here, and in the following section on Semple, I draw on David N. Livingstone, "The Climate of War: Violence, Warfare, and Climatic Reductionism," Wiley International Reviews: Climate Change 6, No. 5 (2015): 437-444.
} 
the community to unionism." It could all be captured in a formula approaching a climatic syllogism: "Climate tendencies facilitate the abolition of slavery in a cold country, but oppose it in one that is warm." 17

The sense of eschatological inevitability in humanity's following a script written in the main by climate brought with it a sense of moral relief in the wake of the bloodshed. As Draper remarked: "Now when we appreciate how much the actions of men ... are determined by climate and other natural circumstances, our animosities lose much of their asperity, and the return of kind feelings is hastened." Climate's actions had the effect of relieving political history of the excessive burdens of moral responsibility. For once readers grasped how climate had ghost-written different histories in North and South, "more philosophical, more enlarged, more enlightened, and, in truth, more benevolent views of each other's proceedings" could be fostered. ${ }^{18}$ The appeal of climatic predestinarianism can readily be discerned. It delivered explanatory simplicity, political self-justification, and ethical absolution. "Indeed," as Draper's biographer Donald Fleming puts it, "one might suppose that the chief convenience - and possibly the chief defect - of the 'climatic' view of history was to by-pass ethical concerns altogether." 19

The environmental foundations of the Civil War also figured prominently in the thinking of the Kentucky geographer and disciple of Friedrich Ratzel, Ellen Churchill Semple (18631932). ${ }^{20}$ Drawing on the work of "older geographers like Montesquieu," she insisted that climate not only modified human physiology, but also governed the "temperament" and "energy" of different peoples and thus their "efficiency" as "economic and political agents." By now, the Montesquieuan cosmos had been translated into Darwinian argot. The "climatic control" of the ecology of human settlement only served to intensify "the struggle for existence" between human groups. And yet it delivered the self-same polarized world ruptured along a north-south divide. Nature had "fixed the mutual destiny of tropical and temperate zones." The "greater industrial efficiency" that the temperate world enjoyed was simply a consequence of the brute fact that the tropics were fated to act as its supplier. The economic history of the United States bore witness to just such polarities. In New England it quickened economic development allowing access to "a nearby tropical trade in the West Indies" as well as to "sub-tropical products in the southern colonies." Likewise, the northern peoples of the Old World were "energetic, provident, serious, thoughtful," while their southern counterparts displayed precisely the same "easy-going, improvident ... emotional, imaginative" qualities which "among the negroes of the equatorial belt degenerate into grave racial faults." ${ }^{21}$ For Semple, as indeed for the Harvard geologist Nathaniel Southgate Shaler who spoke of the "geological distribution of politics," Civil War politics followed

\footnotetext{
${ }^{17}$ Draper, History of the American Civil War, Vol. 1, pp. 20, 21-22, 242, 342

${ }^{18}$ Draper, History of the American Civil War, Vol. 1, pp. iii, 37

${ }^{19}$ Donald Fleming, John William Draper and the Religion of Science (Philadelphia: University of Pennsylvania Press, 1950), p.119. Ascribing slavery to climate was an abiding theme. In his 1868 White Supremacy and Negro Subordination, John H. Van Evrie, an American physician, found in climate the major force of race history. To him a "northern climate" was "fatal to the negro", since "the tropics" were "the natural center of existence of the negro". J.H. Van Evrie, White Supremacy and Negro Subordination or, Negroes a Subordinate Race, and (so-called) Slavery its Normal Condition (New York: Van Evrie, Horton \& Co., 1868), pp. 148, 212. This work was largely a republication of his earlier antebellum Negroes and Negro Slavery: The First, an Inferior Race - the Latter, Its Normal Condition (Baltimore: John D. Toy, ca. 1853).

${ }^{20}$ Innes M. Keighren, Bringing Geography to Book: Ellen Semple and the Reception of Geographical Knowledge (London: I.B. Tauris, 2010)

${ }^{21}$ Ellen Churchill Semple, Influences of Geographic Environment on the Basis of Ratzel's System of Anthropogeography (New York: Henry Holt, 1911), pp. 608, 610, 611, 616, 618, 620
} 
pedology, slavery was a matter of soil, and morality mapped on to meteorology. ${ }^{22}$ In the final two paragraphs of her influential Influences of Geographic Environment, she summarised her climatic philosophy of civilization - an edifice constructed of materials quarried from Montesquieu, Tylor, Ratzel, and Darwin:

Most of the ancient civilizations originated just within the milder but drier margin of the Temperate Zone, where the cooler air of a short winter acted like a tonic upon the energies relaxed by the lethargic atmosphere of the hot and humid Tropics; where congenial warmth encouraged vegetation, but where the irrigation necessary to secure abundant and regular crops called forth inventiveness, coöperation, and social organization, and gave to the people their first baptism of redemption from savagery to barbarism ... As the Tropics have been the cradle of humanity, the Temperate Zone has been the cradle and school of civilization. Here Nature has given much by withholding much. Here man found his birthright, the privilege of the struggle. ${ }^{23}$

In the introduction to his controversial Civilization and Climate of 1915, the Yale geographer and eugenicist Ellsworth Huntington (1876-1947) likewise found in Buckle and Montesquieu support for his assurance that "climate is the most important factor in determining the status of civilization." Like Draper and Semple, he cast his eye on American slavery from time to time insisting that climate was the most potent of all the forces that produced contrasts between northern and southern states. Indeed he judged that slavery "failed to flourish in the North not because of any moral objection to it, for the most godly Puritans held slaves, but because the climate made it unprofitable." ${ }^{24}$ High moral principle was nothing more than low economic pragmatism.

Huntington's climatic philosophy was fully in keeping with the outlook of Draper and Semple. But in other ways he decisively moved beyond their static historicism by headlining the role that climate change played in the history of civilization. Long convinced by the evidence from tree-ring analysis, Huntington urged in his 1907 Pulse of Asia that climatic "pulsations" had played a determining role in human affairs. It boiled down to one conclusion: "long-continuing changes of climate have been one of the controlling causes of the rise and fall of the great nations of the world." From the data he collected, Huntington was sure that the previous two millennia had witnessed "a widespread and pronounced tendency toward aridity" and that, while increasing drought was a "dire calamity, giving rise to famine and distress," dry conditions in turn brought about "the fall of dynasties and empires, the rise of new nations, and the growth of new civilizations." ${ }^{25}$ Desiccation had determined the shape of human history time and time again by channelling the direction in which the narrative moved. ${ }^{26}$ "Insurrections, wars, and massacres" could all be traced back to "deficiency of rain" he judged. Taking the specifics of Chinese Turkestan as proxy for

\footnotetext{
22 Nathaniel Southgate Shaler, Kentucky: A Pioneer Commonwealth (Boston: Houghton, Mifflin, 1884), pp. 23233. On Shaler more generally, see David N. Livingstone, Nathaniel Southgate Shaler and the Culture of American Science (Tuscaloosa: University of Alabama Press, 1987)

${ }^{23}$ Semple, Influences of Geographic Environment, p. 635

${ }^{24}$ Ellsworth Huntington, Civilization and Climate (New Haven: Yale University Press 1915), pp. 2, 23

${ }^{25}$ Ellsworth Huntington, The Pulse of Asia. A Journey in Central Asia Illustrating the Geographic Basis of History (Boston: Houghton Mifflin, 1907), pp. 382, 13, 14

${ }^{26}$ On the desiccation thesis more generally see Richard Grove, Green Imperialism: Colonial Expansion, Tropical Island Edens and the Origins of Environmentalism, 1600-1860 (Cambridge: Cambridge University Press, 1995); Diana K. Davis, The Arid Lands: History, Power, Knowledge (Cambridge, MA: MIT Press, 2016)
} 
global history, Huntington announced, with the enthusiasm of a new convert who has stumbled upon a universal truth, that "Everywhere in arid regions we find evidence that desiccation has caused famines, depopulation, raids, wars, migrations, and the decay of civilization". ${ }^{27}$

Huntington's fascination with the climatic origins of civilization was part-and-parcel of his long-standing interest in medical climatology. Using neo-Hippocratic-sounding language, he analyzed the influence of high-altitude environments on red corpuscle count, temperature fluctuations and death rates, and weather influences on pneumonia and influenza. ${ }^{28}$ Soon he was characterizing whole terrestrial zones in the language of medicalmeteorological excellence. Cartography proved to be a useful rhetorical device. And so he constructed maps correlating the distribution of "climatic energy" in the United States with health data derived from Life Insurance companies. Thereby he could map the world's climatic regimes according to the bi-polar categories of healthful and disease-ridden, stimulating and crippling.

Pursuit of these preoccupations was fully in keeping with Huntington's eugenic enthusiasms. ${ }^{29}$ From around 1910 he was in touch with like-minded intellectuals: John $\mathrm{H}$. Kellogg of the Health and Efficiency League of America, the Cambridge theologian W. R. Inge who lamented the declining birth-rate among old stock American families, and Henry Fairfield Osborn, eugenicist and president of the American Museum of Natural History. ${ }^{30}$ Later, in 1934, Huntington himself became president of the American Eugenics Society. During these years he devoted his energies to the whole issue of birth season in order to ascertain the most favourable months of the year for conception and parturition.

In his 1938 Season of Birth, Huntington argued in Darwinian fashion that the most suitable season for human development had been determined by "the selective effect of the climate in which the species Homo sapiens originated during the glacial period." ${ }^{31}$ At the same time he explored the impact of seasonality on such eugenic themes as sex ratios, race, longevity, insanity, genius, and criminal behaviour drawing on the reproductive biologist Walter Heape, the Finnish philosophical anthropologist Edvard Westermarck, the Italian demographer Corrado Gini who held the presidency of several eugenics organisations, and the criminologist Cesare Lombroso. He had been toying with comparable ideas for well over twenty years. A chapter on "The Ideal Climate" in Civilization and Climate summarised his research on the most suitable conditions for factory operatives to perform their tasks. Huntington seized on these numbers to sketch a global geography of climatic excellence which turned out to be concentrated in a few "chief portions of the globe" - England, North America's Pacific northern coast, and New Zealand. ${ }^{32}$

\footnotetext{
${ }^{27}$ Huntington, Pulse of Asia, pp. 374, 379.

${ }^{28}$ Ellsworth Huntington, Weather and Health: A Study of Daily Mortality in New York City (Washington: Bulletin of the National Research Council, no. 75, 1930), pp. 1-161; Ellsworth Huntington, World-Power and Evolution (New York: Yale University Press, 1919); Ellsworth Huntington, "The Control of Pneumonia and Influenza by the Weather", Ecology 1 (1920): 6-23

${ }^{29}$ See David N. Livingstone, "Darwinian Hippocratics, Eugenic Enticements and the Biometeorological Body", in Martin Mahony and Samuel Randalls (eds), Weather, Climate and the Geographical Imagination (Pittsburgh: University of Pittsburgh Press, in press)

${ }^{30}$ These are identified in Colm Lavery, "Geography and Eugenics in Britain and the United States, 1900 1950", PhD dissertation, Queen's University Belfast, 2015

${ }^{31}$ Ellsworth Huntington, Season of Birth: Its Relation to Human Abilities (New York: John Wiley \& Sons, 1938),

p. $v$

${ }^{32}$ Huntington, Civilization and Climate, p. 129
} 
Huntington did all in his power to disseminate his eugenic vision, one in which population quality, climatic influence, and immigration restriction held pride of place. In 1935 he produced a volume originally intended as an expansion of Leon Whitney's 1923 Eugenics Catechism, a manual widely distributed to learned societies, schools and churches. Entitled Tomorrow's Children: The Goal of Eugenics and published in conjunction with the directors of the American Eugenics Society, Huntington's replacement catechism prominently addressed issues such as differential birth rates, population policy, and eugenic legislation. The handbook catechized readers on the nature of "eugenic selection," the methods of birth control, sterilization, and the like. It also called attention to the problems of immigration. "The eugenist believes that if we permit immigration, we ought to take stringent measures to make sure of the quality of the immigrants." And of course climate was the key determinant of quality. As he declared of "tropical peoples," "much of their inefficiency is due to the debilitating effects of the climate and of the diseases which it fosters." 33

In these several ventures Huntington enjoyed the support of a number of medical practitioners, notably William F. Petersen (1887-1950) and Clarence A. Mills (1891-1974) both of whom drew freely on his work. Petersen, a Chicago physician and a professor of pathology and bacteriology at the University of Illinois College of Medicine, did much to cultivate the science of biometeorology. Self-consciously portraying his endeavours as Hippocratic - his Hippocratic Wisdom came out in 1945 - he devoted his seven-volume The Patient and the Weather to elucidating the medical influence of meteorology. Petersen marshalled this evidence in support of his belief that the human body was what he called a "cosmic resonator." The organic rhythms that governed nearly every aspect of human health were "largely meteorologically conditioned and reflected even minor change to a surprising degree." ${ }^{34}$ Soon Petersen was operating at quite some distance from clinical medicine. In 1943, he published Lincoln-Douglas: The Weather as Destiny, a volume intent on connecting in causally compelling ways climatic forces with the life-paths of Abraham Lincoln and his political opponent Stephen Douglas. Shortly he would tell the readers of his Man-Weather-Sun that the human body's "organic reactions" to atmospheric circumstances was "reflected in cultural cycles, in the waxing and waning of religious and ethical concepts, in social revolution, in mass migrations and in wars." ${ }^{35}$ So it is not at all surprising that in the final chapters of this work he turned to Huntington's Season of Birth to buttress his conviction that mental ability was causally linked to climatic variability; ${ }^{36}$ and to The Revolutions of Civilisation by Flinders Petrie, the English Egyptologist, who used meteorological data to explain the rise and fall of civilisations. ${ }^{37}$

Mills, another key figure in the nascent biometeorological circle, was Professor of Experimental Medicine at the University of Cincinnati. ${ }^{38}$ Mills's early efforts to ascertain the somatic effects of climate resulted in the publication of Medical Climatology: Climatic and

\footnotetext{
${ }^{33}$ Ellsworth Huntington, Tomorrow's Children: the Goal of Eugenics (New York: John Wiley, 1935), pp. 29, 95, 27

${ }^{34}$ William F. Petersen, The Patient and the Weather. Vol 3. Mental and Nervous Diseases (Ann Abor: Edward Bros, 1937), p. 327; William F. Petersen, The Patient and the Weather. Vol. 1, Part 2. Autonomic Integration (Ann Arbor: Edward Bros, 1936), p. 159

${ }^{35}$ William F. Petersen, Man-Weather-Sun (Springfield: Charles C. Thomas, 1947), p. xii

${ }^{36}$ Huntington, Season of Birth; Cesare Lombroso, The Man of Genius (London: Walter Scott, 1891)

${ }^{37}$ W.M. Flinders Petrie, The Revolutions of Civilisation (London: Harper, 1922).

${ }^{38}$ Meyer claims that Mills was "second only to Huntington as a promoter of determinism". William B. Meyer, Americans and their Weather (Oxford: Oxford University Press, 2000), p. 171
} 
Weather Influences in Health and Disease in 1939. Here he scrutinized the influence of climatic conditions on metabolic, cardiovascular and infectious diseases. But like both Huntington and Petersen, Mills cultivated a more general climatic philosophy of culture which he happily deployed for causes dear to the hearts of eugenicists. Historically he ascribed the triumphs of ancient Chinese civilization, the rise of early Greece, the French Revolution, and the like to the vicissitudes of climate. In terms of economics, Mills connected business cycles with what he called "weather stimulation" and "human energy." His fascination with climatological energetics became a dominating preoccupation and shaped his global vision. And so he eagerly embarked on the project of drawing up a hierarchical catalogue of the world's regions arranged in "descending order of climatic energy." He characterised the "storm belt of North America" as a zone with "one of the most invigorating climates the earth has to offer, and there human physical development shows clearly the effects of the intense climatic drive." ${ }^{39}$ By contrast, "Africa - 'darkest Africa'" had "little to offer for human development," and Asia was "likewise damned by climate." 40

On the cyclical character of climatic pulsations, the use of tree-ring data to chart long term fluctuations, patterns of storm pathways, and the mapping of climatic energy, Mills relied on Huntington's authority. At the same time, like other eugenicists, he was severely exercised over immigration. In Living with the Weather, he laid out his view on "Climatic Stimulation and the Immigration Question," concluding with the observation that "the day of unrestricted migration of large masses of people should not be permitted to return. With the knowledge we now have of climatic effects, due foresight would prevent a repetition of past errors." Migrants coming from "a less to a more stimulating climate" could not cope with the higher energy atmosphere and would always remain misfits in their new meteorological environment. "Far too long has immigration been considered from the economic aspect," he concluded; "what it now needs is a concern for its biologic results and possibilities." 41 In Mills' eyes, declining bio-power was the net result of immigration from climatically undesirable regions of the world.

\section{Enduring Legacy}

During the decades that followed, climate determinism fell into disrepute in many groves of the academy. But it did not entirely disappear. It flourished in a lengthy work by Stephen Rosen in 1979 entitled Weathering: How the Atmosphere Conditions Your Body, Your Mind, Your Moods - and Your Health. A kind of biometeorology primer for a popular audience, it contained more references to Petersen than to any other source with Huntington and Mills also featuring. Rosen, a physicist who published on cosmic ray origin theory, made it clear from the first page that he was intent on cultivating a comprehensive meteorological metaphysics. ${ }^{42}$ "The atmosphere energizes us," he began. "It has engineered the appearance, the development, the evolution, the racial differentiation of Homo sapiens perhaps even the creation of human genius." Later he declared that the "average

\footnotetext{
${ }^{39}$ Clarence A. Mills, Living with the Weather (Cincinnati: Caxton Press 1934), p. 188; Clarence A. Mills, Medical Climatology: Climatic and Weather Influences in Health and Disease (London: Bailliére, Tindall \& Cox, 1939), p. 14

${ }^{40}$ Mills, Living with the Weather, pp. 13, 14. See also Clarence A. Mills, World Power and Shifting Climates (Boston: Christopher Publishing House, 1963), p. 64

${ }^{41}$ Mills, Living with the Weather, pp. 149-150

${ }^{42}$ Stephen Rosen, Youth, Middle-Age, and You-Look-Great (New York: Prospect Press, 2013). <IS THIS THE ORIGINAL PUBLICATION DATE?> Yes. It's his autobiographical reflections.
} 
temperature in a country conditions its religion, its ethics, and the size of its standing armies." So it is hardly surprising that to support his climatic reductionist reading of civilization and his speculations on the social manifestations of what he called climatic energy, he invoked the authority of Huntington who had "made the persuasive case that climate stimulates achievement. No great civilization, he argued, ever flourished in polar or tropical regions. He mapped the world's climates according to how much energy they induce in man, what he called climatic efficiency." 43

Perhaps more disturbing was the ease with which he turned to Raymond $\mathrm{H}$. Wheeler, soon to be author of Climate: The Key to Understanding Business Cycles, to confirm that in "cooler climates man is more vigorous, more aggressive, more persistent, stronger physically, larger, braver in battle, healthier, and less prone to sexual indulgence. In warm climates man is more timid, smaller, physically weaker and less courageous but more inclined to physical pleasures, more effeminate, lazier, and less aggressive." Compared with inhabitants of cooler regimes, his readers were told, "the warmer races were considered to be emotionally less stable and dependable." ${ }^{44}$

Variants of the climate-civilization thesis have been further rejuvenated over the past few decades, as the implications of climate change have gripped historical imaginations. In a sequence of popular archaeological works, Brian Fagan of the University of Southern California accords priority to climate in human destiny as sub-titles such as "El Niño and the Fate of Civilizations," "How Climate Changed Civilization," and "Climate Change and the Rise and Fall of Civilizations" plainly advertize. ${ }^{45}$ What is noticeable about Fagan's diagnosis is that it is not simply climate, but climate change, that is the engine power of historical transformation. Thus his readers are told that, like "Norse conquests, cathedrals are a consequence of a global climatic phenomenon, an enduring legacy of the Medieval Warm Period"; and that flips in the North Atlantic Oscillation and the advent of El-Niños have brought about climatic conditions that have "caused civilizations to collapse." ${ }^{46}$ By the same token, climate change could provide a stimulus to invention. In the face of its volatility, human groups could put their knowledge of plants to novel uses and develop new foodgathering and crop-watering technologies. In these circumstances, climate acted as a trigger to innovation. The sense of climate compulsion is certainly conspicuous in these potted scenarios. And it is the same today: "the climate will have its sway in human events." 47 In the collapse of numerous civilizations as Fagan envisages them, climate, if not the only causal force, provides him with what Lucian Boia calls the "coup de grâce." ${ }^{48}$

In his prize-winning panorama of global history, Guns, Germs and Steel (1997), the physiologist, ecologist and environmental historian Jared Diamond set out to demonstrate how geography, not race, shaped the destiny of Europeans, Asians, Africans, native

\footnotetext{
${ }^{43}$ Stephen Rosen, Weathering: How the Atmosphere Conditions Your Body, Your Mind, Your Moods - and Your Health (New York: M. Evans, 1979), pp. xi, 105, 113, 94

${ }^{44}$ Rosen, Weathering, pp. 91, 92. Here Rosen drew on Raymond H. Wheeler, "The Effect of Climate on Human Behavior in History" which originally appeared in Transactions of the Kansas Academy of Science 46 (1943), 33 51

${ }^{45}$ Brian Fagan, Floods, Famines, and Emperors: El Niño and the Fate of Civilizations (New York: Basic Books, 1999); Brian Fagan, The Long Summer: How Climate Changed Civilization (London: Granta Books, 2004); Brian Fagan, The Great Warming: Climate Change and the Rise and Fall of Civilizations (New York: Bloomsbury Press, 2008)

${ }^{46}$ Fagan, Little Ice Age, p. 21; Fagan, Floods, Famines, pp. 114, 109

${ }^{47}$ Fagan, Little Ice Age, p. xviii

48 Lucian Boia, The Weather in the Imagination (London: Reaktion Books, 2005), p. 163
} 
Americans, and aboriginal Australians. In a remarkably ambitious undertaking to provide nothing less than "a short history of everybody for the last 13,000 years," Diamond persistently reiterated his conviction that "the striking differences between the long-term histories of peoples of the different continents have been due not to innate differences in the peoples themselves but to differences in their environments." From the outset, he made it clear that lurking behind all the "proximate causes" of why some societies "became disproportionately powerful and innovative" lay a far more fundamental cause - the Primum Mobile of historical transformation. Taking the measure of that force was precisely his quarry. His answer was reminiscent of Buckle: food production. In Diamond's vision, it was the mechanics of food provision that "determined which peoples became history's have-nots, and which became history's haves," and where advanced civilizations would develop. ${ }^{49}$

Behind all this lay elemental environmental realities. So while Diamond eschewed "the supposed stimulatory effects of ... cold climate and the inhibitory effects of hot, humid, tropical climates on human creativity and energy," he reinscribed climatic determinism in another key. Again and again behind Diamond's comparative geography of domestic plant and animal cultivation lurked the iron will of climate. As he put it in a generalizing principle couched in the language of Darwinian adaptationism: "Each plant population becomes genetically programmed, through natural selection, to respond appropriately to signals of the seasonal regime under which it has evolved." ${ }^{20}$ In the polity of plants, climate reigned supreme. Consequently it ruled no less imperiously in human affairs. For to Diamond global history is fundamentally a story of food and fate. The means of food production, he asserts, "determined which peoples became history's have-nots, and which became history's haves", where advanced civilizations would develop, and which languages would triumph in the world-wide clash of cultures. ${ }^{51}$

David Landes's widely applauded The Wealth and Poverty of Nations, published in 1998, began by reflecting on the sorry demise of Geography as a university subject in the United States during the 1940s. Landes attributed its disappearance to the excesses of environmental determinism as championed by figures like Huntington. "In spite of much useful and revealing research," he ventured, "Huntington gave geography a bad name." Landes explained: "He was so impressed with the connections between physical environment and human activity that he attributed more and more to geography ... In the end, he was classifying civilizations hierarchically and assigning the best - what he defined as the best - to the favors of climate." In consequence, Geography had the misfortune to be tarred with a racist brush and therefore emitted "a sulfurous odor of heresy." 52

Be that as it may, Landes insisted that the subject's discrediting was, in the last analysis, because of its irreducible honesty - it told "unpleasant truth." It told that "life is unfair, unequal in its favors." So having just pronounced the death of Geography in one incarnation he immediately resurrected it in another. When laying out the geography of economic "failure," Landes's first port of call was climate. Its effects included everything from the production of perspiration in what he calls "sweaty" climates, to the siesta, a cultural

\footnotetext{
49 Jared Diamond, Guns, Germs and Steel: A Short History of Everybody for the Last 12,000 Years (London: Chatto and Windus, 1997), pp. 405, 10, 94

${ }^{50}$ Diamond, Guns, Germs and Steel, pp. 22, 184

51 Diamond, Guns, Germs and Steel, p. 94

52 David S. Landes, The Wealth and Poverty of Nations: Why Some Are So Rich and Some So Poor (London: Abacus, 1998), pp. 3, 4
} 
adaptation "designed to keep people inactive in the heat of the day." Historically, tropical climates induced slavery. They also encouraged "the proliferation of life forms hostile to man" which breed rapidly and encourage "faster transmission of disease." Cold is better. Winter "is the great friend of humanity" for it wipes out parasites. A kind of snow morality prevails. So he divided the globe, if not exactly into the pestilential and the paradisal, certainly into something fairly close. As he summed it up in Hobbesian tones: "Life in poor climes ... is precarious, depressed, brutish." ${ }^{13}$ Noting the strong resemblance between Landes's venture and Montesquieu's project, Boia comments: "Here we have geography and climate rehabilitated as the foundations of human history." 54

In his celebrated The Spirit of the Laws, Montesquieu remarked, in reflecting on the mores and manners of nations, that the "empire of the climate is the first, the most powerful of all empires." 55 That idea itself has exerted lasting imperial power. In the United States it colonized an expansive territory among geohistorians, practitioners of medical climatology, and enthusiasts for eugenics. More recently, in the wake of growing concerns about anthropogenic climate change it has continued to ignite the imaginations of writers seeking fundamental explanations for the wealth of nations and the rise and fall of civilizations. At times the idea has cast a dark fatalism over humanity's future; at others, climate's frightening force has been marshalled in the hope of inciting behavioral change; on still other occasions, its threatening power has been used as justification for military investment and aggressive immigration policies. None of this, of course, is to suggest that the climate does not influence human culture in vitally important ways. Nor is it to deny the reality of either natural or anthropogenic climate change. Neither is it to diminish the threat that climate change poses to the very survival of the human species. But it is to acknowledge the power of human agency in the making of history and geography. What the story I have sketched above does seem to confirm, however, is that the recent reinvigoration of climate reductionism bears out Oskar Spate's prescient observation in 1960 that while his generation had been "assured that determinism is as dead as the dodo," he thought it wiser to characterise it as that "Immortal Bird, not born for death". ${ }^{56}$

\footnotetext{
${ }^{53}$ Landes, Wealth and Poverty of Nations, pp. 4, 5, 6, 7, 8, 14

${ }^{54}$ Boia, Weather in the Imagination, p. 114

${ }^{55}$ Montesquieu, The Spirit of Laws, Book XIX, §14

56 O. H. K. Spate, "Quantity and Quality in Geography," Annals of the Association of American Geographers, 50

(1960): 377-394, on p. 382
} 